\title{
Profil Penalaran Siswa SMA dalam Menyelesaikan Masalah Logika Berdasarkan Perbedaan Gaya Kognitif
}

\author{
Nur Aliya, Didik Hermanto, Buaddin Hasan
}

(C) 2020 JEMS (Jurnal Edukasi Matematika dan Sains)

This is an open access article under the CC-BY-SA license (https://creativecommons.org/licenses/bysa/4.0/) ISSN 2337-9049 (print), ISSN 2502-4671 (online)

\begin{abstract}
Abstrak:
Penelitian ini bertujuan untuk mendeskripsikan profil penalaran siswa SMA dalam menyelesaikan masalah logika berdasarkan gaya kognitif impulsif dan reflektif. Penelitian ini merupakan penelitian deskriptif kualitatif. Subjek penelitian ini terdiri dari satu orang siswa bergaya kognitif impulsif, dan satu siswa bergaya kognitif reflektif. Intrumen pendukung yang digunakan adalah Tes gaya kognitif Matching Familiar Figure Test (MFFT), pedoman wawancara dan tugas penyelesaian masalah (TPM). Teknik pengumpulan data menggunakan Teknik wawancara berbasis tugas penyelesaian masalah. Teknik analisis data menggunakan reduksi data, penyajian data, penarikan kesimpulan/verivfikasi. Hasil penelitian menunjukkan bahwa siswa impulsif menyelesaikan masalah dengan cara mengubah kalimat implikasi dari soal menjadi simbol implikasi, kemudian membuat tabel kebenaran dari ekivalensi implikasi, namun terdapat kesalahan dalam penulisan simbol dari salah satu pernyataan. Selanjutnya siswa impulsif menuliskan dan menyebutkan kalimat pernyataan yang diperoleh sebagai hasil penyelesaian. Siswa impulsif memberikan alasan atau bukti terhadap satu atau beberapa solusi dengan cara menentukan pernyataan kedua sebagai pernyataan berkuantor dan menuliskan contoh dari kalimat berkuantor dengan simbol kuantor universal dan eksponensial. Siswa reflektif menyelesaikan masalah dengan cara menuliskan apa yang diketahui dan yang ditanya dari soal, kemudian memberi garis bawah pada masing-masing pernyataan dan memberi tanda dengan simbol pernyataan. Selanjutnya siswa menuliskan kalimat implikasi dengan simbol implikasi. Selanjutnya siswa reflektif menuliskan dan menyebutkan penyelesaian yang diperoleh sambil melingkari hasil yang diperoleh tersebut, kemudian dengan nada ragu siswa menyebutkan kalimat "ingkaran dari implikasi dalam bentuk simbol.
\end{abstract}

Kata Kunci: Penalaran, gaya kognitif, logika

\begin{abstract}
:
This study describes high school students' reasoning profiles in solving logic problems based on impulsive and reflective cognitive styles. This research is a qualitative descriptive study. The subjects of this study consisted of one impulsive cognitive style student and one reflective cognitive style student. The supporting instruments used were the Matching Familiar Figure Test (MFFT) cognitive style test, interview guidelines, and problem-solving tasks (TPM). The data collection technique uses the problem solving task-based interview technique. Data analysis techniques using data reduction, data presentation, concluding / verification. The results showed that impulsive students solved the problem by changing the implication sentence from the question to the implication symbol, then making a truth table from the implication equivalence. Still, there were errors in writing the symbol of one of the statements. Next, the impulsive students wrote and mentioned the statement sentences obtained as a result of completion. Impulsive students provide reasons or evidence for one or several solutions by determining the second statement as an official statement and writing an example of an office sentence with universal and exponential quantor symbols. Reflective students solve problems by writing down what is known and what is asked from the questions, then underlining each statement, and marking it with a statement symbol. Then the students wrote the implication sentence with the implication symbol. Furthermore, the reflective students wrote down and mentioned the solutions obtained while circling the results obtained. With a tone of doubt, the students said the sentence "negation of implications in the form of symbols.
\end{abstract}

Keywords: Reasoning; Cognitive Style; logic

\section{Pendahuluan}

Dalam kehidupan sehari-hari manusia secara sadar atau tidak sadar akan selalu berurus-

Nur Aliya, STKIP PGRI Bangkalan

nuraliya393@gmail.com

Didik Hermanto, STKIP PGRI Bangkalan

didikhermanto@stkippgri-bkl.ac.id

Buaddin Hasan, STKIP PGRI Bangkalan

buaddinhasan@stkippgri-bkl.ac.id 
an dengan matematika. Dari urusan kehidupan yang kecil atau hal yang paling sederhana (misalnya jual beli di pasar) sampai dengan hal yang paling tinggi atau kompleks (misalnya teknologi pesawat terbang), semuanya pasti melibatkan ilmu matematika. Dalam ilmu Pendidikan, matematika merupakan ilmu dasar yang mendukung perkembangan ilmu lainnya (Turmudi, 2010). Melalui proses pembelajaran, terutama pada pendidikan matematika, siswa akan memperoleh suatu ilmu yang sangat berguna bagi kehidupannya. Sejalan hal tersebut, Qomariyah (2016) juga menyatakan bahwa pelajran matematika merupakan salah satu pelajaran yang sangat penting untuk diajarkan kepada siswa. Matematika merupakan ilmu yang penggunaannya harus dilakukan secara logis dan rasional. Hal tersebut memposisikan matematika berkaitan sangat erat dengan penalaran siswa, karena salah satu tujuan utama pembelajaran matematika yaitu meningkatkan kemampuan penalaran siswa dalam menyelesaikan permasalahan yang dijumpai pada kehidupan sehari-hari. Oleh karena itu seorang guru haruslah memotivasi siswa untuk bernalar dalam menyelesaikan masalah matematis dengan cara siswa tidak dipaksa dalam akalnya karena dapat menjadikan siswa frustasi dan menganggap matematika pelajaran yang berat atau pelajaran yang sangat tidak mudah dipahami di sekolah.

Penalaran merupakan satu hal yang sangat penting yang tidak dapat dipisahkan dalam proses pembelajaran matematika. Karena matematika itu sendiri merupakan ilmu pengetahuan yang diperoleh melalui bernalar, Tinggi (Mikrayati, 2016). Sejalan dengan hal tersebut, Tukaryanto (2018) juga menyampaikan bahwa pentingnya penalaran matematis sangat berpengaruh dengan pembelajaran matematika di sekolah. Karena dengan kemampuan penalaran yang baik siswa akan mudah memahami materi matematika yang diberikan, sebaliknya jika siswa berkemampuan rendah dalam bernalar, maka akan sulit dalam memahami materi matematka yang diberikan. Banyak para ahli yang telah menyatakan pentingnya penalaran bagi pendidikan matematika, di antaranya: Pentingnya penalaran matematis sangat berpengaruh dengan pembelajaran matematika di sekolah (Tukaryanto, 2018).

Penalaran menjadi bagian terpenting untuk mencapai kebenaran secara rasional, karena penalaran pada pendidikan matematika memiliki kesamaan dengan penalaran pada kehidupan sehari-hari untuk menyelesaikan permasalahan (Azar dkk, 2016). Penalaran matematika merupakan fondasi dalam memahami permasalahan yang akan dicari penyelesaiannya. Oleh karena itu, siswa perlu diberikan latihan bernalar melalui pemberian suatu masalah, dimana dengan menyelesaikan suatu permasalahan, maka akan tumbuh argumen-argumen dalam diri siswa.

Penalaran merupakan sebuah proses berfikir seseorang, dimana untuk dapat bernalar diperlukan proses berpikir yang logis. Proses berpikir selalu muncul ketika seseorang menghadapi suatu permasalahan dan ia ingin menyelesaikannya. Hal tersebut dapat diartikan bahwa penalaran dan penyelesaian masalah memiliki keterkaitan yang sangat erat. Kemampuan bernalar merupakan kebutuhan pokok dalam menyelesaikan suatu masalah. Dengan kemampuan bernalar, seseorang akan dapat lebih mudah menyelesaikan permasalahan yang sedang dihadapi. Penalaran yang merupakan proses berpikir secara logis dapat dipengaruhi oleh gaya kognitif siswa, karena pada dasarnya proses berpikir merupakan proses kognitif yang terjadi pada diri seseorang. Gaya kognitif adalah karakteristik atau ciri khas seorang siswa dalam memperoleh informasi (Sanjaya, 2018). Gaya kognitif merupakan suatu cara yang sangat disukai individu dalam mengatur dan memproses suatu informasi (Heinemen 
\& mulia, 1995). Gaya kognitif terbagi menjadi dua kriteria, yaitu gaya kognitif field dependentfield independent dan impulsif-reflektif.

Gaya kognitif impulsif-reflektif merupakan sebuah cara anak dalam mengerjakan atau menyelesaikan suatu permasalahan dengan kemampuan kecermatan/ketelitian yang dimiliki. Hal tersebut sanganlah dibutuhkan untuk menyelesaikan sebuah permasalahan terutama dalam menyelesaikan permasalahan matematika, Gaya kognitif impulsif dan gaya kognitif reflektif pertama kali dikemukakan oleh Kagan (Azhar, 2016). Gaya kognitif impulsif memiliki karakteristik cepat dalam menjawab sebuah permasalahan, tetapi tidak cermat/tidak teliti, sehingga jawaban masalah cenderung salah. Sedangkan gaya kognitif reflektif memiliki karakteristik lambat dalam menjawab sebuah permasalahan, tetapi cermat/teliti sehingga jawaban masalah yang diperoleh cenderung benar.

Berdasarkan beberapa urain di atas dirasa perlu adanya penelitian yang mengaitkan antara penalaran siswa, penyelesaian masalah, dan gaya kognitif, sehingga pada penelitian ini, peneliti ingin mengungkap lebil dalam tentang profil penalaran siswa SMA dalam menyelesaikan masalah logika berdasarkan perbedaan gaya kognitif impulsif dan reflektif. Dalam matematika, beberapa peneliti telah merumuskan indikator yang dapat digunakan untuk mengidentifikasi penalaran siswa, di antaranya: Yulianita (2018) merumuskan 8 indikator penalaran yang meliputi 1) mengidentifikasi suatu masalah, 2) menggambarkan suatu permasalahan, 3) menghubungkan elemen-elemen yang telah diperoleh dari suatu permasalahan, 4) menerapkan konsep yang sudah diketahui pada suatu permasalahan, 5) mengajukan dugaan, 6) menguji dugaan-dugaan yang sudah ditemukan dan menyusun bukti, 7) memberikan alasan terhadap solusi yang sudah di temukan dan menyusun bukti, dan 8) menarik kesimpulan. Bazir, (2015) juga menyampaikan 7 indilator penalaran yang harus dicapai oleh siswa, yaitu: 1) kemampuan dalam menyajikan pernyataan matematika baik secara lisan, tulisan, gambar atau diagram, 2) kemampuan dalam mengajukan suatu dugaan, 3) kemampuan dalam memanipulasi matematika, 4) kemampuan dalam mencari bukti dan memberikan bukti terhadap kebenaran atas solusi yang sudah ditemukan, 5) kemampuan dalam menarik kesimpulan dari suatu pernyataan, 6) kemampuan dalam memeriksa kebenaran dari suatu argument, 7) kemapuan dalam menemukan pola atau sifat untuk membuat generalisasi.

Dalam penelitian ini, indikator penalaran yang digunakan untuk mengidentifikasi penalaran siswa merujuk pada indikator penalaran yang dirumuskan oleh Bazir (2015), yaitu:1) melakukan manipulasi matematika, 2) mengajukan dugaan serta dapat menguji dan menyusun bukti dari pernyataan, 3) menarik kesimpulan dari suatu pernyataan, dan 4) memberikan alasan atau bukti terhadap satu/beberapa solusi. Masalah yang digunakan adalah masalah logika, karena Logika merupakan salah satu bidang ilmu yang mengkaji prinsip-prinsip penalaran yang benar dan penarikan kesimpulan yang absah, baik yang bersifat deduktif maupun yang bersifat induktif. Logika merumuskan hukum-hukum yang dapat digunakan sebagai alat untuk menilai apakah hasil suatu pimikiran benar atau absah. Gaya kognitif yang digunakan untuk melihat profil penalaran siswa adalah gaya kognitif reflektif dan impulsif. Sedangkan masalah yang digunakan sebagai tugas penyelesaian masalah adalah masalah logika. Selanjutnya indikator penalaran siswa dalam menyelesaikan masalah logika disajikan pada tabel berikut 
Indikator penalaran Siswa Dalam Menyelesaikan Masalah Logika

\begin{tabular}{|l|l|l|}
\hline \multicolumn{2}{|c|}{ Indikator penalaran } & \multicolumn{1}{c|}{ Deskriptor } \\
\hline 1) $\begin{array}{l}\text { Melakukan manipulasi matematika, } \\
\text { 2) } \begin{array}{l}\text { Mengajukan dugaan serta dapat } \\
\text { menguji dan menyusun bukti dari }\end{array}\end{array}$ & $\begin{array}{l}\text { Cara menuliskan model matematika } \\
\text { pernyataan. }\end{array}$ \\
$\begin{array}{l}\text { Menarik kesimpulan dari suatu } \\
\text { pernyatan. }\end{array}$ & $\begin{array}{l}\text { Cara mengelesaikan permasalahan. } \\
\text { hasil yang telah diperoleh secara lisan } \\
\text { maupun tulisan }\end{array}$ \\
$\begin{array}{l}\text { Memberikan alasan atau bukti } \\
\text { terhadap satu/beberapa solusi. }\end{array}$ & $\begin{array}{l}\text { Cara memberikan alasan serta bukti yang } \\
\text { jelas terhadap hasil yang telah diperoleh } \\
\text { secara lisan maupun tertulis. }\end{array}$ \\
\hline
\end{tabular}

\section{Metode}

Penelitian ini bertujuan mendeskripsikan profil penalaran siswa dalam menyelesaikan masalah logika berdasarkan gaya kognitif. Data yang dikumpulkan berupa kalimat hasil wawancara kepada subjek. Berdasarkan tujuan dan data yang dikumpulkan, maka penelitian ini merupakan penelitian deskriptif kualitatif. Instrumen bantu yang digunakan dalam penelitian ini terdiri dari instrument tes gaya kognitif, Tugas Penyelesaian Masalah (TPM), dan pedoman wawancara. Instrument tes gaya kognitif digunakan dalam rangka penentuan subjek penelitian, sedangkan tugas penyelesaian masalah dan pedoman wawancara digunakan dalam rangka pengumpulan data penalaran siswa dalam menyelesaikan masalah logika.

Pengumpulan data gaya kognitif siswa dalam rangka pemilihan subjek penelitian dilakukan dengan teknis tes, sedangkan pengumpulan data penalaran siswa dalam menyelesaikan masalah dilakukan dengan wawancara berbasis tugas penyelesaian masalah. Wawancara dengan subjek penelitian dilakukan sesaat setelah subjek menyelesaikan tugas. Dalam rangka mendapatkan data yang kredibel maka dilakukan triangulasi waktu, yaitu membandingkan dua data wawancara yang diperoleh dari sumber yang sama dalam waktu yeng berbeda. Teknik analisis data yang digunakan adalah teknik analisis data menurut Miles and Huberman, yaitu reduksi data, penyajian data, dan penarikan kesimpulan. Analisis data difokuskan pada indikator penalaran siswa, yaitu

Pemilihan subjek dilakukan menggunakan tes gaya kognitif, berupa tes MFFT (Matching Familiar Figure Test) yang dikembangkan oleh Warli, (2010). Karena kemampuan matematika dan jenis kelamin dikontrol, maka subjek penelitian dipilih dari siswa dengan jenis kelamin dan tingkat kemampuan matematika yang sama. Hal tersebut dilakukan agar hasil penelitian tidak bias.

\section{Hasil dan Pembahasan}

Berdasarkan hasil analisis data yang telah dilakukan, diperoleh profil penalaran siswa SMA dalam menyelesaikan masalah logika berdasarkan gaya kognitif. Instrumen Tugas 
Penyelesaian Masalah (TPM) yang digunakan untuk pengumpulan data penalaran siswa dapat disajikan sebagai berikut.

Tugas Penyelesaian Masalah (TPM) 1:

Diketahui suatu implikasi : "Jika hujan sangat deras, maka semua sawah tergenang air". Tentukan negasi/ingkaran dari implikasi tersebut!

Tugas Penyelesaian Masalah (TPM) 2:

Diketahui suatu implikasi : "Jika kemarau panjang, maka semua sawah akan kering". Tentukan negasi/ingkaran dari implikasi tersebut!

Berdasarkan hasil analisis data diperoleh profil penalaran siswa SMA dalam menyelesaikan masalah logika berdasarkan gaya kognitif sebagai berikut.

1. Profil Penalaran Siswa SMA dengan gaya kognitif Impulsif Dalam Menyelesaikan Masalah Logika

Siswa dengan gaya kognitif impulsive melakukan manipulasi matematika dengan cara menuliskan pernyataan pada soal kemudian menulis dan mengungkapkan dengan lancar apa yang diketahui dan apa yang ditanya dalam bentuk simbol matematika dan mengubah kalimat soal menjadi simbol implikasi. Dalam mengajukan dugaan, menguji dan menyusun bukti pernyataan, siswa menuliskan dan menyebutkan penyelesaian masalah pada soal dengan cara menulis tabel kebenaran dari ekivalensi implikasi dan menceritakan perihal ekivalensi tersebut, namun pada saat menuliskan tabel kebenaran siswa tidak teliti dalam menulis simbol " $\neg p$ " sehingga yang tertulis pada tabel kebenaran adalah " $\neg q$ ". Dalam menarik kesimpulan, siswa menuliskan dan menyebutkan kalimat penyelesaian, yaitu "hujan sangat deras dan beberapa sawah tidak tergenang air" Selanjutnya siswa memberikan alasan atau bukti terhadap satu/beberapa solusi dengan cara menentukan $\mathrm{q}$ sebagi pernyataan berkuantor dan menuliskan contoh dari kalimat berkuantor dalam bentuk simbol $\forall$ dan $\exists$ sebagai contoh dari pernyataan berkuantor.

2. Profil Penalaran Siswa SMA dengan gaya kognitif Reflektif Dalam Menyelesaikan Masalah Logika

Siswa dengan gaya kognitif Reflektif melakukan manipulasi matematika dengan cara menuliskan apa yang diketahui pada soal yaitu sebuah kalimat implikasi dengan simbol " $\mathrm{p}$ " dan " $\mathrm{q}$ " kemudian membuat garis dari $\mathrm{p}$ dan $\mathrm{q}$ dan menuliskan simbol dari implikasi " $\mathrm{p} \rightarrow \mathrm{q}$ " kemudian siswa mengubah kalimat soal menjadi simbol implikasi. Siswa mengajukan dugaan, menguji dan menyusun bukti pernyataan dengan cara menuliskan dan menyebutkan penyelesaian masalah kemudian setelah mendapatkan hasil, siswa melingkari hasil akhir penyelesaian tersebut. Dalam menarik kesimpulan dari suatu pernyataan, siswa menuliskan hasil dari penyelesaian dan menyebutkan kesimpulan "kemarau panjang dan beberapa sawah tidak kering, kemudian menuliskan pada lembar jawaban. Selanjutnya siswa memberikan alasan atau bukti terhadap satu/beberapa solusi dengan cara menyebutkan dengan ragu kalimat "ingkaran dari implikasi p $\Lambda \neg q$ " sebagai alasan atau bukti.

\section{Simpulan}

Berdasarkan analisis data dan pembahasan, maka profil penalaran siswa SMA dalam menyelesaikan masalah logika dapat disimpulkan sebagai berikut. Siswa impulsif melakukan manipulasi matematika dengan cara menulis dan menyebutkan dengan lancar apa yang diketahui dan apa yang ditanya dalam bentuk simbol matematika, yaitu mengubah kalimat 
implikasi dari soal menjadi simbol implikasi. Dalam mengajukan dugaan, menguji dan menyusun bukti pernyataan, siswa impulsif menyelesaikan masalah dengan cara membuat tabel kebenaran dari ekivalensi implikasi, namun terdapat kesalahan dalam penulisan simbol dari salah satu pernyataan. Dalam menarik kesimpulan, siswa impulsif menuliskan dan menyebutkan kalimat pernyataan yang diperoleh sebagai hasil penyelesaian. Siswa impulsif memeberikan alasan atau bukti terhadap satu atau beberapa solusi dengan cara menentukan pernyataan kedua sebagai pernyataan berkuantor dan menuliskan contoh dari kalimat berkuantor dengan simbol kuantor universal dan eksponensial.

Siswa dengan gaya kognitif reflektif melakukan manipulasi matematika dengan cara menuliskan apa yang diketahui dan yang ditanya dari soal, kemudian menggaris bawahi masing-masing pernyataan dan memberi tanda dengan simbol pernyataan. Selanjutnya siswa menuliskan kalimat implikasi dengan simbol implikasi. Siswa reflektif mengajukan dugaan, menguji dan menyusun bukti pernyataan dengan cara menuliskan dan menyebutkan penyelesaian yang diperoleh sambil melingkari hasil yang diperoleh tersebut. Dalam menarik kesimpulan dari suatu pernyataan, siswa reflektif menuliskan dan menyebutkan hasil penyelesaian yang diperoleh, kemudian memberi alasan atau bukti terhadap satu/beberapa solusi dengan cara menyebut kalimat "ingkaran dari implikasi dalam bentuk simbol dengan nada ragu.

\section{Daftar Rujukan}

Arikunto, S. (2010). Prosedur penelitian suatu pendekatan praktik. Jakarta: PT. Rineka Cipta.

Azhar, Sudia, M., \& Kadir. (2016). Profil penalaran matematis siswa SMA yang bergaya kognitif Impulsif -Reflektif dalam memecahkan masalah matematika ditinjau dari perbedaan gender. Jurnal pembelajaran berpikir matematika, Vol.1, No.1, Februari 2016:21-30, 23-24.

Bazir, M. A. (2015). Kemampuan penalaran siswa dalam pemecahan masalah matematis ditijau dari gaya kognitif . Jurnal pendidikan matematika FKIP Ussula vol.3 no.1, 107

Henemen, P.L., \& Mulia, G. (1995). Cognotive and Learning style. Boston: Allyn \& Bacon.

Mikrayati. (2016). Meningkatkan kemampuan penalaran matematis melalui pembelajaran berbasis masalah. Suska Joernal Of Mathematics Education, Vol.2, No.2, 2016 ,(pISSN:2477-4758 | e-ISSN:2540-9670) Hal.97-102.

Qomariyah, N. (2016). Profil pemahaman siswa SMA dalam menyelesaikan masalah persamaan kuadrat ditinjau dari perbedaan kepribadian ektrovert dan introvert. Jurnal apotema Vol.2 No.1, Januari 2016, ISSN: 2407-8840 Hal:87

Sanjaya, N. M. (2018). Pengaruh metode problem solving dan gaya kognitif terhadap kemampuan analisis siswa. Indonesia Jurnal of Economics Education, Vol.1, No.1,2018, 6572. https:/ / ejournal.upi.edu/index.php/IJEE/article/view/10788

Sugiyono, P. (2012). Metode penelitian Kuantitatif, Kualitatif, Dan RED. Bandung: ALFABETA, $\mathrm{CV}$. 
Sugiyono. (2015). metode penelitian pendidikan pendekatan kuantitatif, kualitatif, dan RED . Bandung: ALFABETA

Tukaryanto, Hendikawati, P., \& Nugroho, S. (2018). Meningkatkan kemampuan penalaran matematika dan percaya diri sisw kelas $\mathrm{X}$ melalui model discovery learning. PRISMA Vol.1,2018,Hal.656-662.

Turmudi (2010). Pembelajaran Matematika Kini dan Kecenderungan Masa Mendatang: Dipublikasikan dalam Buku Bunga Rampai Pembelajaran MIPA, JICA FPMIPA.

Warli. (2010). profil kreatifitas siswa yang ber-gaya kognitif reflektif dan bergaya kognitif impulsif dalam memecahkan masalah geometri. Surabaya: Disertasi PPS UNESA.

Yulianita, M. (2018). Profil penalaran matematis siswa kelas XI SMAN 1 Tanjunganom materi barisan berdasarkan gaya kognitif tahun 2017/2018. https://www.google.com/url?sa=t\&source=web\&rct=j\&url 